
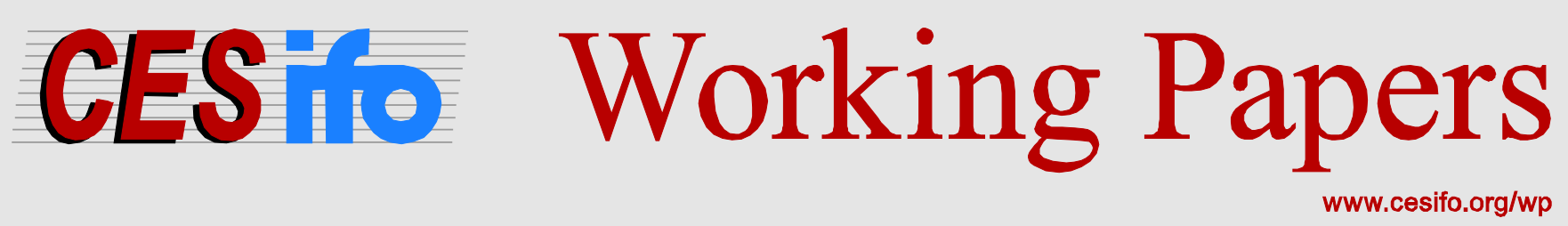

\title{
Improving the Availability of Trade Finance in Developing Countries: An Assessment of Remaining Gaps
}

\author{
Marc Auboin
}

\begin{abstract}
CESIFO WORKING PAPER NO. 5784
CATEgory 7: MONETARY POLICY AND INTERNATIONAL FinANCE

FEBRUARY 2016
\end{abstract}

An electronic version of the paper may be downloaded

- from the SSRN website:

- from the RePEc website:

- from the CESifo website:

WWW.SSRN.cOm

Www.RePEc.org

www.CESifo-group.org/wp 


\title{
Improving the Availability of Trade Finance in Developing Countries: An Assessment of Remaining Gaps
}

\begin{abstract}
While conditions in trade finance markets returned to normality in the main routes of trade, the structural difficulties of poor countries in accessing trade finance have not disappeared - and might have been worsened during and after the global financial crisis. In fact, there is a consistent flow of information indicating that trade finance markets have remained characterized by a greater selectivity in risk-taking and flight to "quality" customers. In that environment, the lower end of the market has been struggling to obtain affordable finance, with the smaller companies in the smaller, poorer countries most affected. In an area where statistics are difficult to find, this paper looks at recent available information and provides background on the persistent and significant market gaps for trade finance in developing countries, notably in Africa and developing Asia. It discusses various initiatives in which the WTO and partner institutions are involved to alleviate in part this situation.
\end{abstract}

JEL-Codes: F130, F340, F360, O190, G210, G320.

Keywords: trade financing, cooperation with international financial institutions, coherence, G20, developing countries.

\author{
Marc Auboin \\ Economic Research and Statistics Division \\ World Trade Organization \\ Rue de Lausanne 154 \\ Switzerland - 1211 Geneva 21 \\ Marc.Auboin@wto.org
}

All views expressed are those of the author and cannot be attributed to the WTO Secretariat or WTO Members. Research assistance was provided by Mr. Alexandre Lauwers, intern. It is well acknowledged. 
1 I NTRODUCTI ON ........................................................................................................ 3

2 TRADE FI NANCE MARKETS: RESI LI ENT, BUT SUBJ ECT TO DI SLOCATI ON DURI NG FI NANCI AL CRI SES ............................................................................ 3

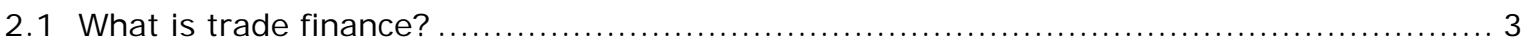

2.2 While being very safe, trade finance markets can be subject to dislocation during

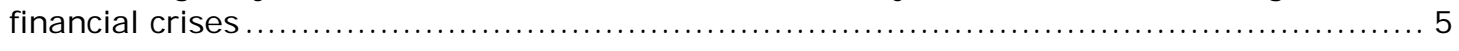

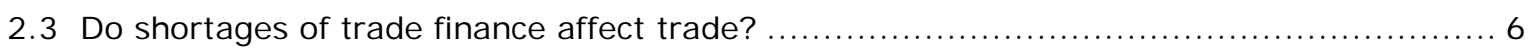

3 STRUCTURAL DI FFI CULTIES I N DEVELOPI NG COUNTRI ES ................................. 7

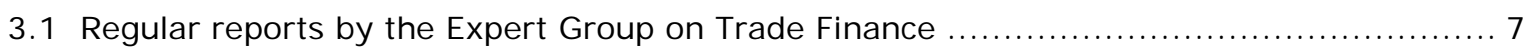

3.2 The G-20 had expressed concerns and recommendations regarding the situation

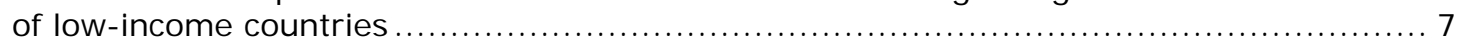

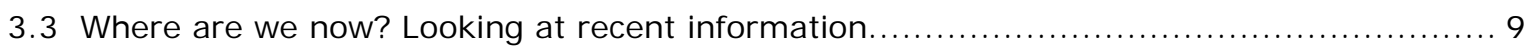

4 ADDRESSI NG TRADE FI NANCE DI FFI CULTIES I N DEVELOPING COUNTRIES

4.1 Supporting MDBs in establishing a global network of trade finance facilitation programs....

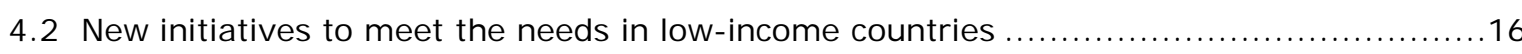

4.3 Avoiding the unintended consequences of Basel III on trade finance, particularly for developing countries....

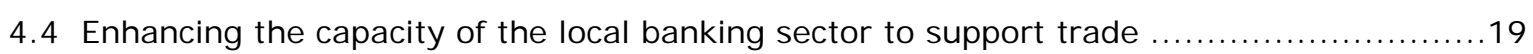

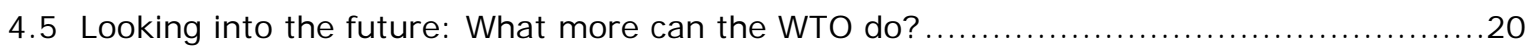

\section{LIST OF CHARTS, TABLES AND BOXES}

Chart 2.1 Change in the composition of trade finance business, IMF-BAFT Trade

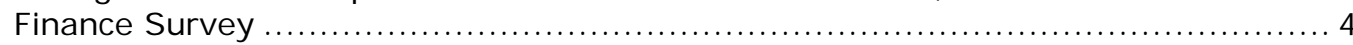

Table 2.1 Analysis of short-term trade finance products - risk characteristics $\ldots \ldots \ldots \ldots \ldots \ldots 5$

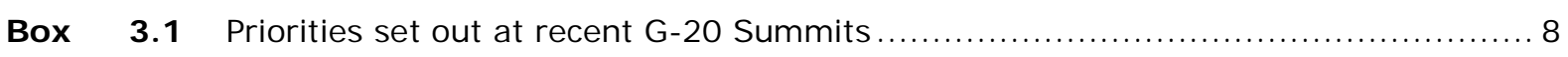

Chart 3.1 African banks' reasons for rejecting letters of credit applications, AfDB 2014...... 10

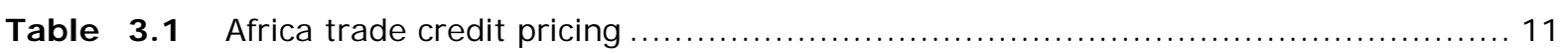

Chart $\mathbf{3 . 2}$ Factors limiting companies' ability to obtain trade finance, ADB $(2014) \ldots \ldots \ldots \ldots 12$

Chart 3.3 The extent in which access to trade finance forms an obstacle to company

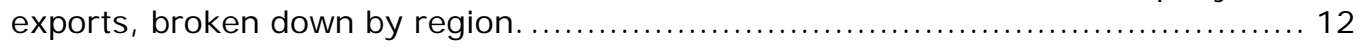

Chart 3.4 The most problematic factors for exporting in Africa, WEF 2013 $\ldots \ldots \ldots \ldots \ldots \ldots \ldots 13$

Chart 3.5 The most problematic factors for exporting in Pacific Alliance and in Latin

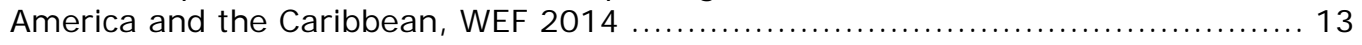

Chart 3.6 Impediments to Trade Finance according to respondent banks, ICC Global

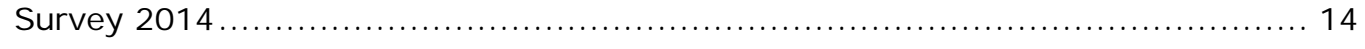

Chart 3.7 Public views on the main barriers in connecting firms to value chains $\ldots \ldots \ldots \ldots \ldots 15$

Table 4.1 Overview of the main trade facilitation programs................................ 16

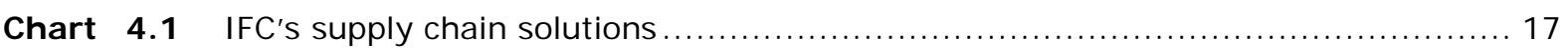

Box 4.1 Operating in new frontier countries: the ADB's trade finance program in Myanmar..... 


\section{I NTRODUCTI ON}

Until the financial crises of the 1990s and that of 2008-09, trade finance had been taken for granted. However, the recent financial crisis revealed that trade finance markets can be subject to dislocation, making policy interventions necessary given the strong linkage between the availability of trade finance and trade flows. Following the G-20 support "package" implemented in 2009-10, conditions returned to normality in the main markets, albeit not everywhere and not for everyone.

The structural difficulties of poor countries in accessing trade finance have not disappeared - and might have been worsened during and after the banking crisis. In fact, there is a consistent flow of information indicating that trade finance markets have remained characterized by a greater selectivity in risk-taking, a flight to "quality" customers, as well as a retrenchment of global lenders on home operations due to new capital, compliance and margin pressures. It is also clear that in some regions, in particular the poorest, production networks are moving faster than the ability of the local financial sectors to support the new trade that they create. In that environment, the lower end of the market still face the greatest problems to obtain affordable finance, with the smaller companies in the smaller, poorer countries most affected. As a result, the demand for trade finance programs of multilateral financial institutions, a concessional form of trade finance and an indicator of the global trade finance gap, had grown to a previously unknown magnitude. The importance of resource-pooling and co-financing between the existing providers of trade finance, and the mobilization of public-sector actors are thus most needed, and particularly well suited to addressing some of these structural obstacles.

The paper is organized as follows. Section 2 shows that trade finance markets, while being at the short-term, low-risk and high-collateral end of the credit spectrum, are prone to turbulences, if not stoppage, in times of financial crises. Section 3 looks at recent evidence, mostly survey-based, regarding quantitative estimates of trade finance gaps globally and regionally, as well as the main impediments limiting the supply and the access of trade finance in developing countries. Section 4 discusses the efforts deployed by Multilateral Development Banks, including a number of new initiatives, together with the WTO's advocacy and mobilisation work, to address trade finance difficulties at the low end of the market.

\section{TRADE FI NANCE MARKETS: RESI LIENT, BUT SUBJECT TO DISLOCATION DURING FI NANCI AL CRI SES}

\subsection{What is trade finance?}

Finance is the lubricant of commerce. A very large share of trade transactions are supported by some form of financing, e.g. a credit, guarantee and/or insurance. For example, a credit is most often required to bridge the gap between the time at which exporters wish to be paid (at dispatch, at the latest; with the order, at the earliest), and the time at which importers will pay (at the earliest, on receipt of the merchandise). The credit can be accorded by the buyer to the seller directly ("buyer's credit") or inversely by the seller to the buyer, without banking intermediation. Such "open account" financing may nonetheless require the intervention of banks, not the least to manage the large amount of "receivables" and "payables" involved in modern global supplychains. The ability of firms to extend direct credit to their trading counterparties may be enhanced by possibilities to either discount their receivables (to forfaiting companies), and the possibility to mitigate payment risk by purchasing trade credit insurance.

Alternatively, banks may support the trade transaction by bearing most of the payment risk. The importer's bank assists by providing a letter of credit to the exporter (or the exporter's bank) providing for payment upon presentation of certain documents related to the trade transaction. The exporter's bank may make a loan to the exporter on the basis of the export contract. Letters of credit, while still dominant in South-South trade, involve a relatively long and labour-intensive process. With the expansion of global supply-chains, buyers and sellers have asked their banks to provide the necessary liquidity and credit to fund the numerous and regular orders on "open account" basis. This less cumbersome form of finance may actually prove more risky when the economic cycle faces a reversal. The rapid expansion of open account finance has been a major feature of trade finance trends in recent years. 
As noted by the Bank of International Settlements (BIS, 2014), there is no single, comprehensive source of statistics allowing for an evaluation of trade finance's exact composition and market size. BIS data captures part of the "bank-intermediated" share of trade finance, although "coverage differs significantly across countries, and in many cases is limited". ${ }^{2}$ According to previous global surveys by the International Monetary Fund (IMF) and the Bankers' Association for Finance and Trade (BAFT), the share of bank intermediated and non-bank intermediated trade finance seems to be relatively comparable, as shown in Chart 2.1, although some banking institutions argue that the share of open account transactions is dominant in global supply chain transactions. ${ }^{3}$

\section{Chart 2.1 Change in the composition of trade finance business, I MF-BAFT Trade} Finance Survey (percentage of respondents)

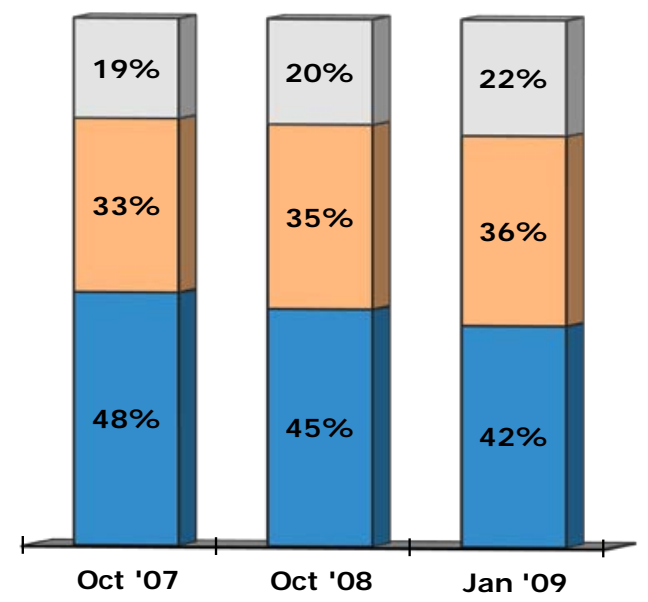

Cash-in-Advance Transactions

Bank-I ntermediated Transactions

Open Account Transactions

Source: IMF-BAFT (International Monetary Fund-Bankers' Association for Finance and Trade) (2009), "IMFBAFT Trade Finance. Survey: A Survey among Banks Assessing the Current Trade Finance Environment.", report by FImetrix for IMF and BAFT, Washington, DC.

Based on the assumption that the largest share of the US\$18 trillion of annual trade transactions is not paid cash and involves some form of finance (credit, insurance or guarantee), the market for trade finance, considered in its widest definition, is very large - certainly well above US\$10 trillion annually. For bank-intermediated short-term trade finance only, the BIS (2014) considered that a "flow of some US\$6.5-8 trillion was provided during 2011, of which around US\$2.8 trillion was letters of credit". The BIS adds that "about one-third of global trade is supported by one or more bank-intermediated trade finance products". "The remainder was financed by inter-firm trade credit" (non-bank intermediated). Inter-firm credit is increasingly supported by the global factoring industry. ${ }^{5}$

While the commercial risks involved in an international trade transaction seem in principle to be larger than in a domestic trade transaction (risk of non-payment, risk of loss or alteration of the merchandise during shipment, exchange rate risk), trade finance is actually considered to be a particularly safe form of finance, as it is underwritten by strong collateral and documented credit operations. The low risk nature of short-term trade finance is supported by data collated in the International Chamber of Commerce's (ICC) Trade Finance Loss Register, set up in 2011.

\footnotetext{
${ }^{2}$ Bank-intermediated trade finance includes to a large extent letters of credit and pre-shipment trade loans of less than one year.

3 I MF-BAFT surveys have been discontinued in 2011 and merged with that of the International Chamber of Commerce (ICC). In its 2014 Global Trade and Finance Survey, the ICC reports that commercial letters of credit as a proportion of overall trade finance products are in slow but steady decline, from $44 \%$ of total export trade finance products in 2011 to $41 \%$ in 2014, and from 44\% in import trade finance in 2011 to $36 \%$ in 2014 . Cash transactions seem to be stable at 15 to $17 \%$ of the total.

${ }^{4}$ This estimate is short of a few percentage points of that of the ICC and the BAFT.

${ }^{5}$ Broadly speaking, factoring is a financial transaction in which receivable assets are sold to a third party (generally a financial institution, a factoring company, forfeiter, bank) against cash or is used as collateral against cash or lending. Given the very high rate of payment in international trade, international trade invoices, contracts are highly valued collateral or assets. In international trade, factoring is called forfaiting when the exporter sells its receivable to a forfeiter.
} 
According to the ICC 2013 Global Risks - Trade Finance Report, the average transaction default rate on short-term international trade credit is no more than 0.021 per cent, of which 57 per cent is recovered though the sale of the underlying asset, the merchandise. ${ }^{6}$ Table below provides more detailed risk characteristics across specific categories of short-term trade finance instruments.

Table 2.1 Analysis of short-term trade finance products - risk characteristics

\begin{tabular}{|l|l|l|l|l|l|}
\hline Total 2008-11 & $\begin{array}{l}\text { Transaction } \\
\text { default rate }\end{array}$ & $\begin{array}{l}\text { I mplied } \\
\text { maturity } \\
\text { (days) }\end{array}$ & $\begin{array}{l}\text { Recovery } \\
\text { rate }^{1}\end{array}$ & $\begin{array}{l}\text { Defaulted trans- } \\
\text { action loss rate }^{2}\end{array}$ & $\begin{array}{l}\text { Specific } \\
\text { transaction-level }_{\text {loss rate }}\end{array}$ \\
\hline $\begin{array}{l}\text { I mport L/ Cs } \\
\text { Export Confirmed L/ Cs }\end{array}$ & $0.020 \%$ & 80 & $71 \%$ & $42 \%$ & $0.008 \%$ \\
$\begin{array}{l}\text { Loans for I mport } \\
\text { Loans for Export: Bank } \\
\text { risk } \\
\begin{array}{l}\text { Loans for Export: } \\
\text { Corporate risk }\end{array}\end{array}$ & $0.016 \%$ & 70 & $40 \%$ & $68 \%$ & $0.011 \%$ \\
$\begin{array}{l}\text { Performance } \\
\text { Guarantees }\end{array}$ & $0.029 \%$ & 110 & $45 \%$ & $64 \%$ & $0.010 \%$ \\
\hline Total & $0.034 \%$ & 110 & $18 \%$ & $85 \%$ & $0.021 \%$ \\
\hline
\end{tabular}

Note: L/Cs stands for Letters of Credits. ${ }^{1}$ Observed recoveries as a \% of defaulted exposure across products. ${ }^{2}$ Estimated economic loss rate as a percentage of defaulting exposure after discounting and costs.

* Over 2008-2011, the average observed annual issuer-weighted corporate default rates for Aa rated customers was $0.14 \%$

** The total average and the product-level annual transaction-level loss compare favourably with the average observed annual credit loss rate for Moody's customers over the same period of $1.49 \%$.

Source: International Chamber of Commerce, (2013) "Global Risks - Trade Finance Report 2013". ICC Banking Commission.

\subsection{While being very safe, trade finance markets can be subject to dislocation during financial crises}

Despite trade finance being a routine task, it is universal and vital for trading activities. Until the financial crises of the 1990s and 2008-09, trade finance had become easy to take for granted. But the emergency created distortions in the relevant markets that made policy interventions necessary.

The attention of policy-makers had been raised by some severe disturbances experienced in global inter-bank links connecting traders and investors during the Asian and Latin American crises of the late 1990's. At the time, foreign "correspondent" banks reconsidered existing exposures to local banks in the context of solvency crises affecting local financial institutions. The fact that a credit crunch could affect both exports and imports to the point of stoppage, as was seen in Indonesia (WTO, 1998) and elsewhere for several weeks, led the international and trading communities to be concerned about the availability of trade finance during periods of financial crisis. A "debriefing" exercise took place in 2003 and 2004, based on a proposal by the Managing Director of the IMF and the Director-General of the WTO (in a dedicated session of the WTO General Council on Coherence) to create an Expert Group on Trade Finance for a review of "what happened". The group had been created partly in response to the concerns expressed by WTO Members in the WGTDF on the situation of trade finance. The "debriefing exercise" involved experts from the IMF, the World Bank, Multilateral Development Banks, and the private sector; it aimed at identifying possible market failures, best practices and cooperative action in response to the crisis.

The conclusions of this work are contained in IMF (2003); and WTO (2004). Building on such reports, the WGTDF reported to the fifth Ministerial Conference in Cancún that, "based mainly on

6 This would imply a transaction-level economic loss rate of approximately of $0.012 \%$ (i.e. $0.021 \% \times 57 \%$ ) for short-term trade finance transactions. 
experience gained in Asia and elsewhere, there is a need to improve the stability and security of sources of trade finance, especially to help deal with periods of financial crisis. Further efforts are needed by countries, intergovernmental organizations and all interested partners in the private sector, in particular in exceptional circumstances of financial crises" (WTO Document WT/WGTDF/2). The IMF and WTO documents had identified elements of market failure, herd reaction and other disruptive behaviour affecting trade finance, and listed a number of intergovernmental programs aimed at restoring confidence during such periods. The IMF went as far as to recommend a number of steps to be taken, notably the use of multilateral programs to facilitate the financing of trade (see Section 4.1 for a discussion of the main trade finance facilitation programs).

In the heat of the 2009 financial meltdown, the collapse of worldwide trade was accelerated by the shortage of trade finance, linked to the temporary inability of private sector banks to respond to their customers' financing needs. The London G-20 Summit took the initiative to muster US $\$ 250$ billion in additional short-term trade finance and guarantees, based on input provided by the WTO Director-General Expert Group on Trade Finance. This was a most welcome development that helped restore confidence in the market. Large traders were able to benefit from rapid export credit support and risk-sharing mechanisms mobilized by international financial institutions: within a year of implementation, the initiative had helped mobilize US\$170 billion in additional capacity, mainly from export credit agencies, of which $\$ 130$ billion had been used. ${ }^{7}$ In the summer of 2009 , it was felt that the outlook for global trade finance had improved, in part due to improvements in overall financial markets and partly due to a recovery of trade.

\subsection{Do shortages of trade finance affect trade?}

Interest from academia in the role of trade finance has grown in the context of the recent financial crisis and subsequent global economic downturn. The "trade finance" hypothesis has gained popularity among some economists in their search of plausible explanations for the "big trade collapse" of late 2008 to late 2009, when global trade outpaced the drop in GDP by a factor that was much larger than anticipated under standard models. As summarized by Eichengreen and O'Rourke (2012): "the roots of this collapse of trade remain to be fully understood, although recent research has begun to shed light on some of the causes (see Baldwin, 2009; and Chor and Manova, 2009)". While most authors agree that the fall in demand has been largely responsible for the drop in trade flows, the debate focused on the extent to which other potential culprits, such as trade restrictions, a lack of trade finance, vertical specialization, and the composition of trade, may have played a role. $^{8}$ The problem for allocating a proper "share" of the trade collapse to trade finance has been one of measurement, not methodology. Empirical work on trade finance has been limited by the lack of a comprehensive dataset, despite the existence of market surveys pointing to the sharp fall of trade finance during the financial crisis (ICC, 2009; and IMF-BAFT, 2009). Although the exact amount of "missing" trade finance may remain unknown, the literature produced in this context made great progress in highlighting the wider link existing between financial conditions, trade credits and trade.

Firm-level empirical work has considerably helped in establishing this causality. Amiti and Weinstein (2011) established the causality between firms' exports, their ability to obtain credit and the health of their banks. Bricongne et al. (2012) demonstrated that export-oriented firms in sectors more dependent on external finance have been most affected by the crisis, while Chor and Manova (2012) showed that the cost of external finance may prevent firms, originally fit to export, to actually do so. Auboin and Engemann (2013) found a causal link between trade credit and trade at a macro level through a full cycle. Using quarterly data for 91 countries in the period 20052011 , they found that a $1 \%$ increase in trade credit granted to a country leads to a $0.4 \%$ increase in real imports of that country.

\footnotetext{
7 The Reports of the G-20 Group on Expert on Trade Finance, monitoring the G-20 initiative, can be found at: http://www.g20india.gov.in/pdfs/August2010_G20_Trade_Finance_Experts_group.pdf; and at http://17g20.pa.go.kr/Documents/g20 trade finance_experts_august_report_v1.pdf.

${ }^{8}$ Eaton et al. (2011) find that demand shocks can explain between 60 and $80 \%$ of the decline in trade, depending on countries.
} 
As summarized by the BIS (2014, page 27), "changes in final expenditure were the main contributor to the decline in global trade observed during the crisis of 2008-09, (but) given the magnitude of the reduction of trade volumes at the onset of the Great Recession, the unexplained residual after taking into account compositional effects remains quite significant in economic terms. (...) Taken together, the literature suggests that credit shocks, including working capital and trade finance, possible account for $15-20 \%$ of the decline in trade during the crisis". BIS own calculations showed that "tighter financial conditions, surges in risk aversion and dollar funding pressures have all been correlated with declines in trade finance. They also reveal that emerging and developing economies have been more affected in this process than developed countries.

\section{STRUCTURAL DI FFI CULTI ES I N DEVELOPI NG COUNTRI ES}

\subsection{Regular reports by the Expert Group on Trade Finance}

The Director-General's Expert Group on Trade Finance has been instrumental during the crisis and beyond in providing insights on trade finance market trends. The Secretariat reported regularly on the Expert Group's assessments to the WGTDF. The latest report is contained in document WT/WGTDF/W72. Expert Group assessments have also been regularly integrated into the WTO "Monitoring Reports" to the General Council and G-20 meetings (see in particular WTO Document WT/TPR/OV/W/8 of 27 J une 2014).

The prevailing view of the Expert Group is that global trade finance markets stabilized in the course of 2010. In the period 2010-2012, markets experienced several periods of stress, notably at the end of 2011, in the context of deleveraging of banks' balance sheets and the euro-zone crisis. In general, since the end of the financial crisis, leading trade finance banks have been "shedding" assets - in particular European ones - to reduce the size of their balance sheets, in part to comply with new capital adequacy regulations. However, with the expansion of new suppliers of trade finance, notably from large emerging economies, and relatively easy monetary policies, tensions in the main "routes" of international trade subsided in 2013 and 2014.

At the same time, Experts have also highlighted the greater selectivity in risk-taking and flight to "quality" customers in trade finance markets. In particular, they reported on the increasing difficulties faced by low-income countries to access trade finance on affordable terms. Part of these difficulties existed prior to the financial crisis. "Structural" constraints range from the lack of knowhow in local banks to mistrust, resulting in traders having to set aside large collateral requirements for a loan in addition to high fees. These problems in accessing affordable trade finance may have worsened somewhat since the 2009 crisis. The downsizing of some key global financial industry players since 2009 has certainly contributed to this situation. Capital for lending in low-income countries had become scarcer and the selectivity of risks greater, so negative expectations regarding the cost of doing business in poorly (or non-) rated countries translated into higher costs for traders locally, or simply in less finance available. Several global banks had been reducing their network of "correspondent banks" in these countries, thereby limiting the scope of local banks to find suitable counterparties internationally. ${ }^{9}$ Emerging countries' banks, while generally gaining market shares, have not filled the gap, because of the "start-up" cost of doing business in these new countries.

\subsection{The G-20 had expressed concerns and recommendations regarding the situation of low-income countries}

The problems faced by low-income countries (LICS) in accessing affordable trade finance have been taken seriously by the G-20. At the G-20 Summit in Seoul, Heads of States and Governments had been sensitive to the risk of a "trade finance divide", between recovering mainstream markets and, at the "periphery" of grand trade routes, growing difficulties. In the Seoul Summit Document, they asked that "the G-20 Trade Finance Expert Group, together with the WTO Expert Group on Trade Finance and the OECD Expert Credit Group to further assess the current need for trade

\footnotetext{
${ }^{9}$ According to BIS (2014), global banks play a very important role in the market for trade finance. They "appear to account for a quarter to a third of the global supply of bank-intermediated trade finance, with local and regional banks providing the remainder". In 2011, such banks provided US\$2 trillion of the estimated \$6.5-8 trillion of bank-intermediated, short-term trade finance recorded.
} 
finance in LICS, and if a gap is identified, will develop and support measures to increase the availability of trade finance in LICS. We call on the WTO to review the effectiveness of existing trade finance programs for LICS and to report on actions and recommendations as for the consideration by the Sherpas through the G-20 Development Working Group in February 2011". ${ }^{10}$

The report from the WTO Expert Group on Trade Finance was presented to the March 2011 meeting of the G-20 Sherpas. It revealed that only a third of the 60 poorest countries in the world benefited regularly from the services offered under these trade finance programs. The lack of risk mitigation programs in these countries partly explained the very high fees and collateral requirements paid by local importers. Such high fees were out of line with risk statistics revealed by the ICC's Trade Finance Loss Register. Given the strong demand for these programs and their development orientation, the Director-General of the WTO supported the Report' recommendations that the priority was to strengthen trade finance facilitation programs where they existed, and create some where they did not yet exist. From a geographical point of view, priorities were in Africa and Asia.

These priorities were endorsed by Ministerial Reports from the Development Working Group to the G-20 Summits in Cannes (2011) and Los Cobos (2012), as outlined in Box 3.1.

\section{Box 3.1 Priorities set out at recent G-20 Summits}

\section{In Cannes (2011),}

"We recognize that the availability of trade finance continues to be problematic for many countries and that a significant number of countries have not so far received any trade finance support from the Multilateral Development Banks (MDBs). During periods of financial turbulence, maintaining the availability of trade finance will be essential in ensuring the resilience of developing countries. Building on the recommendations of the WTO report, we therefore recommend:

a. the G20 to consider further how best to improve data, including with regard to the existing database on trade finance. This should allow more accurate tracking of trends and monitoring of gaps faced by LICS, including in times of crisis;

b. the establishment of a trade finance facility at the African Development Bank (AfDB), which would mean that all MDBs would then have a trade finance facility in place".

In Los Cobos (2012).

"We should remain vigilant with regards to the outlook on trade finance for developing countries, and LICS in particular. We ask the WTO and World Bank to keep us updated on the availability and trends with respect to trade finance. We will continue to support AfDB efforts to enhance the availability of trade finance in Africa, in particular the on-going work to establish a trade finance facility."

Note: $\quad$ The 2011 and 2012 full reports are available respectively at: http://www.g20dwg.org/documents/pdf/view/359/ and http://www.g20dwg.org/documents/pdf/view/361/.

In line with the priorities set out at recent G-20 Meetings, the Board of Directors and senior management of the African Development Bank agreed at the beginning of 2013 to start a trade finance program for African traders, helping to close a gap in the global support network. As a result of these global programs, the international community is now able to support billions of trade transactions by small and medium-sized enterprises in poor countries, which would not have necessarily received support from private markets.

Progress has also been achieved in the knowledge and understanding of trade finance trends and figures, in cooperation with the BIS and the ICC. The WTO has been instrumental in requesting the ICC to improve market surveys and compiling several sources of market data in the ICC Annual Survey. However, there is still not a single, comprehensive set of official international statistics on trade finance. According to the BIS (2014, page 5): "Aspects of bank-intermediated trade finance are captured by statistics in several countries. For the majority, these data cover only stocks of

${ }^{10}$ The G-20 Seoul Summit Document and the Trade Section of Annex II are respectively available at https://www.g20.org/sites/default/files/g20_resources/library/Seoul_Summit_Document.pdf and http://www.mofa.go.jp/policy/economy/g20_summit/2010-2/annex $\overline{2}$.pdf. 
trade finance on a quarterly basis. Coverage differs significantly across countries, and in many cases is quite limited or unavailable. The partial and heterogeneous nature of the national trade finance data is evident". The BIS acknowledges that further progress on data is likely to take time. ${ }^{11}$

\subsection{Where are we now? Looking at recent information}

\subsubsection{Latest views from the Expert Group on Trade Finance and from WTO Members}

The last report of the Expert Group on Trade Finance (25 April, 2014, WTO Document WT/WGTDF/W72) continued to point to the persistent difficulties faced by small and medium-sized enterprises in low-income countries, as well as in the higher-income countries of Asia, Latin America, the Middle East, and Africa. "The activity of Multilateral Development Banks (MDBs) was a good proxy for the existing market gap", notes the report, and "from this point of view, the demand on MDBs risk mitigation products for trade had never been so high". As regards multilateral efforts, the Group acknowledged that "there was very little appetite by private markets to venture into most of Sub-Saharan Africa, leaving the International Financial Corporation (IFC), the Islamic Development Group (ITFC), and the African Development Bank (AfDB) to fill only part of a financing gap estimated [at a minimum] of US\$30 to 50 billion". The Asian Development Bank had received particularly strong and steady demand from clients in Bangladesh, Pakistan, Sri Lanka, Uzbekistan and Viet Nam. As for the Inter-American Development Bank, their program supported an all-time high (an increase of $57 \%$ on 2012) due to capital movement reversals, higher risk aversion and continued structural weakness in local financial sectors. The report also highlighted that "the European Bank for Reconstruction and Development had been quite active in supporting trade in Ukraine and Russia lately, but also in the Middle East and North Africa region, which was also benefitting from ITFC support (Egypt and other countries). IFC's Global Trade Finance Program products were equally distributed across the world and were in high demand".

Several WTO Members have also brought their own evidence to the discussion. For example, the delegation of Pakistan recently provided the following written statement: "We recognize that for Asian countries, the ADB has been helpful in addressing liquidity shortages and such debilitating factors as risk perception. However, problems still plague the system. For instance, along with an emerging trend of transition to open account, many importers still require letters of credit such that a dual, costly and complex system still prevails, putting an added burden on exporters. The cost of letters of credit has been on the rise for buyers, and banks that tightened or restricted lending with the onset of the crisis have not resumed their prior level of lending. It can be said that the decline has been greater than perhaps justified by fundamentals or risk profile. Evidently, this financing gap has adversely affected our export performance. The loss of liquidity has forced a resort by the exporters to spot foreign exchange for making necessary payments, resulting in an increasing demand for already stressed foreign exchange and further compounding problems. We look forward to WTO's continued interest and action in this area" (WTO Document WT/TPR/OV/M/11).

\subsubsection{Few, but some quantitative estimates}

The determination of a quantitative gap is a difficult exercise in a context in which the availability of trade finance statistics at a global, regional or country level is limited or partial, even in developed countries. Most of the evidence is survey-based, hence providing information of a qualitative nature. However, surveys provide useful information about trends, notably when they are conducted on a regular basis (annual surveys by the ICC and the World Economic Forum; every three years by the research group of the Dutch Ministry of Foreign Affairs, the Centre for the Promotion of Imports from developing countries, CBI). Such surveys are conducted in a rather rigorous manner, from a methodological point of view, and benefit from a large and global

11 In its conclusion, the BIS report says "further steps by the private and public sector could help to improve data availability and quality going forward, and would be likely to have positive implications for the industry. Currently, a more detailed coverage of global trade finance activities via harmonized statistical reporting frameworks is complicated by ongoing changes to market modalities and the lack of agreed definition even amongst banks (...). Consideration could be given to encouraging more general and more uniform public disclosure by banks of the evolution of their trade finance flows and assets. (BIS, id.)" 
coverage (almost 300 banks in over 100 countries for the ICC; thousands of exporting small and medium-sized enterprises for the $\mathrm{CBI}$ ).

Financing gaps seem to be the highest in the poorest countries, notably in Africa and in developing Asia. Regarding the African continent, there are two recent surveys, the most recent emanating from the African Development Bank (2014), which describes itself as producing the most "conservative" estimate of the financing gap in the region. The other study was funded by the European Union for the the African, Caribbean and Pacific Group of States (ACP, 2013), and is on the higher end of gap estimates. The results of both studies are described below.

In the recently released report "Trade finance in Africa" (2014), the African Development Bank surveyed the trade activities of 276 African commercial banks operating in 45 African countries. It found that the market for bank-intermediated trade finance was between US $\$ 330-350$ billion, but could be higher if a significant share of the financing requested by traders had not been rejected. Based on an estimate of such rejections, the conservative estimate for the value of unmet demand for trade finance in Africa was, according to the African Development Bank, of US\$110 billion in 2011 and US\$120 billion in 2012. The main reasons for rejections of the demands for financing are the lack of credit worthiness or history, the insufficient limits granted by endorsing banks to local African issuing banks, the small size of the balance sheets (and capital) of African banks and insufficient US dollar liquidity (see Chart 3.1). Part of these constraints are structural, and can only be addressed in the medium-to-long run: the African banking sector is not very concentrated hence limiting the financing capacity of individual banks -, the lack of US dollar availability is chronic, and many African banks are risk-adverse in view of the limited collateral guarantees presented by small traders. In the light of such constraints, the survey argues that the African Development Bank's trade finance facilitation program, as well as those of other DFIs, are most needed, and particularly well suited to addressing some of these obstacles.

\section{Chart 3.1 African banks' reasons for rejecting letters of credit applications, AfDB 2014}

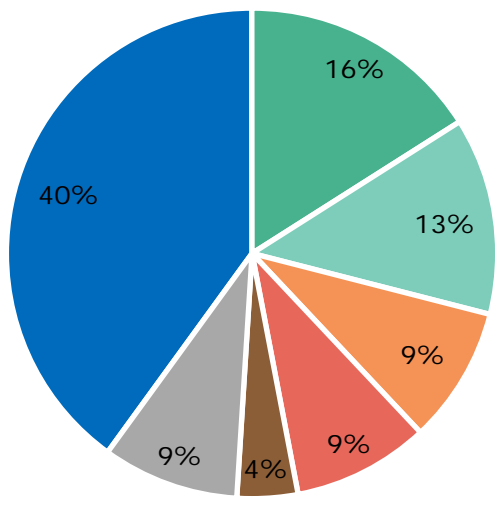

Client credit worthiness

Capital constraint

Balance sheet capacity constraint

Insufficient limits from confirming banks

Limited foreign currency liquidity

Product or instrument limit

Other

Source: $\quad$ African Development Bank (2014), "Trade Finance in Africa", December 2014.

The ACP survey of 2013 is on the higher-end of the financing gap estimate in Africa. It also attempts to estimate the unmet demand for trade finance. In this study, the trade finance gap in Sub-Saharan African countries is evaluated at US $\$ 225$ billion a year, as unmet by the financial system (part of this gap may actually be met by informal sources of finance). According to the study, the main constraints in filling such gaps are the cost and tenors of facilities notably during the periods of crisis; a strong dependency on external sources of trade finance; a vulnerability to external shocks; the limited institutional capacity of local suppliers; and limited financial inclusion (in particular with the limited use of bank accounts).

The level of prices for trade-related lending provides another useful proxy for the trade financing gap. Just like market prices are reflections of supply and demand, the evidence of gaps in certain regions of the world is logically translated in prices on trade finance instruments. Based on the 
spreads for emerging market trade credit instruments published by Omni Bridgeway - a leading firm active in trade finance restructuring -, a large number of African countries have encountered extremely high spreads on trade financing, consistently high over the years as evidenced in Table 3.1. For instance, interest rates on trade loans in 2013 were peaking to $49 \%$ per annum in Kenya and $70 \%$ in Angola. ${ }^{12}$ Apart from a few countries for which political risk may account for the main reason, such prohibitive terms on African countries reflect a disconnect between the perception and actual level of commercial risk.

Table 3.1 Africa trade credit pricing (annual interest rate)

\begin{tabular}{|l|r|r|r|r|}
\hline Country & \multicolumn{2}{|c|}{ April $\mathbf{2 0 1 3}$} & \multicolumn{2}{c|}{ May 2011} \\
\hline Angola* & $65 \%$ & $70 \%$ & $60 \%$ & $65 \%$ \\
\hline Cameroon & $18 \%$ & $24 \%$ & $14 \%$ & $20 \%$ \\
\hline Congo & $22 \%$ & $26 \%$ & $22 \%$ & $26 \%$ \\
\hline Democratic Republic of the Congo & $22 \%$ & $27 \%$ & $16 \%$ & $20 \%$ \\
\hline Ghana & $74 \%$ & $78 \%$ & $78 \%$ & $82 \%$ \\
\hline Kenya* & $39 \%$ & $49 \%$ & $39 \%$ & $49 \%$ \\
\hline Mozambique & $20 \%$ & $26 \%$ & $20 \%$ & $26 \%$ \\
Senegal & $12 \%$ & $16 \%$ & $12 \%$ & $16 \%$ \\
\hline Sudan & $9 \%$ & $14 \%$ & $15 \%$ & $19 \%$ \\
\hline Tanzania & $25 \%$ & $35 \%$ & $10 \%$ & $13 \%$ \\
\hline Uganda & $16 \%$ & $18 \%$ & $14 \%$ & $16 \%$ \\
\hline Zambia & $13 \%$ & $20 \%$ & $13 \%$ & $20 \%$ \\
\hline
\end{tabular}

Note: $\quad$ Trade credits and their documentation differ from case-to-case and price ranges should therefore be considered as benchmark only. Price ranges are based on a monthly compilation of sources and analytics. Liquidity on most instruments is very limited and trading may not have taken places for some time. *Spreads are corrected for inflation.

Source: "Emerging Market Debt Pricing" from Omni Bridgeway, April 2013 and May 2011 issues. See http://www.omnibridgeway.com/ for further information.

Using both a survey and econometric calculations, the Asian Development Bank (2014), estimated that the unmet global demand for trade finance could be as high as US\$1.9 trillion in trade in 2013. ${ }^{13}$ In Asian developing economies alone, the estimated shortage could be as high as US\$ 1.1 trillion, of which US\$700 billion is attributed to India and China, and US\$400 billion to other developing countries in Asia, including the poorest (Bangladesh, Cambodia, Indonesia, Malaysia, Myanmar, Nepal, Pakistan, Sri Lanka, Viet Nam).

Small and medium-sized enterprises (SMEs) are the most credit constrained; half of their requests for trade finance are estimated to be rejected, compared to only $7 \%$ for multinational corporations. With $68 \%$ of surveyed companies reporting that they did not seek alternatives for rejected transactions, trade finance gaps appear to be exacerbated by a lack of awareness and familiarity among companies - particularly smaller ones - about the many types of trade finance products and innovative options which exist on the market (such as supply-chain financing, bank payment obligations and forfaiting). A large majority of firms stated that they would benefit from greater financial education. Finally, price constraints cited by firms appeared also as the key systemic bottleneck to obtaining trade finance (see Chart 3.2). The survey confirms in this case also that the trade finance programs of multilateral development banks help fill such persistent trade finance gaps in Asia and elsewhere.

12 In addition to high interest rates, requirements may include up to three years of financial statements and collateral requirements covering up to $30 \%$ to $50 \%$ of the loans' net present value.

${ }^{13}$ This figure represents an upper limit since responses do not distinguish the quality of proposals for trade finance and the methodology requires extrapolation from partial data. Precisely, the estimated value of the global gap was calculated in two steps: first, the surveyed banks' rejection rate is drawn from the bank's responses to their approximate total value of proposed transactions and to the average percentage of rejected transactions; and second, this reported gap from the surveyed population is then projected to the global banking environment, obtained by weighting surveyed banks assets as a proportion of global assets. 
Chart 3.2 Factors limiting companies' ability to obtain trade finance, ADB (2014) (\% reported by firms as very significant and significant)

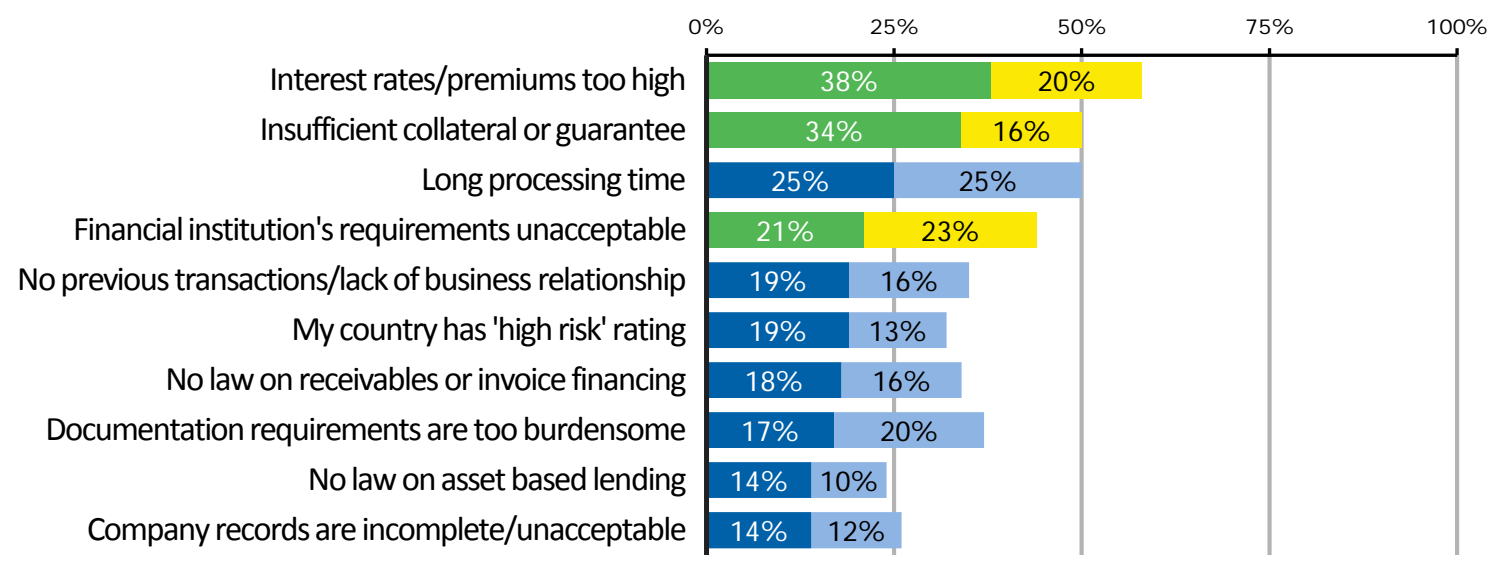

Source: $\quad$ ABD (2014), "ADB trade finance gap, growth, and jobs survey", ADB Briefs No.25.

\subsubsection{Converging qualitative surveys}

An interesting feature of qualitative surveys is to help position the lack of trade finance relative to other structural, supply-side problems faced by exporters in poor countries. Unsurprisingly, lack of access to finance is at the top of concerns when it comes to operating in international markets. A variety of sources indicate that it is a major obstacle for traders in Africa, albeit not only in this region.

The survey released by the Dutch government-CBI (2013), as at the end of 2012, specifically asked to what extent small and medium-sized enterprises exporters in developing countries faced difficulties in accessing trade finance. Three thousand SMEs were contacted in 52 countries. Respondents considered the lack of access to trade finance to be troublesome, particularly for SME exporters. Trade finance shortages affected both exports and turnover, as a result of omitted sales to foreign customers. According to respondents, the local financial sector is often unable to support modern international transactions, such as trade receivable financing. SME exporters were asked whether access to trade finance was a more serious, equally serious or less serious obstacle than three years before. The results showed that, globally, for one third of exporters it was a larger obstacle, while for more than half the situation was unchanged. As shown in Chart 3.3 below, the extent to which access to trade finance deteriorated differed across regions. With respect to sectors, access to trade finance in Africa seemed to have deteriorated more in the agricultural and manufacturing industry than in the tourism industry. The survey is currently being updated.

Chart 3.3 The extent in which access to trade finance forms an obstacle to company exports, broken down by region

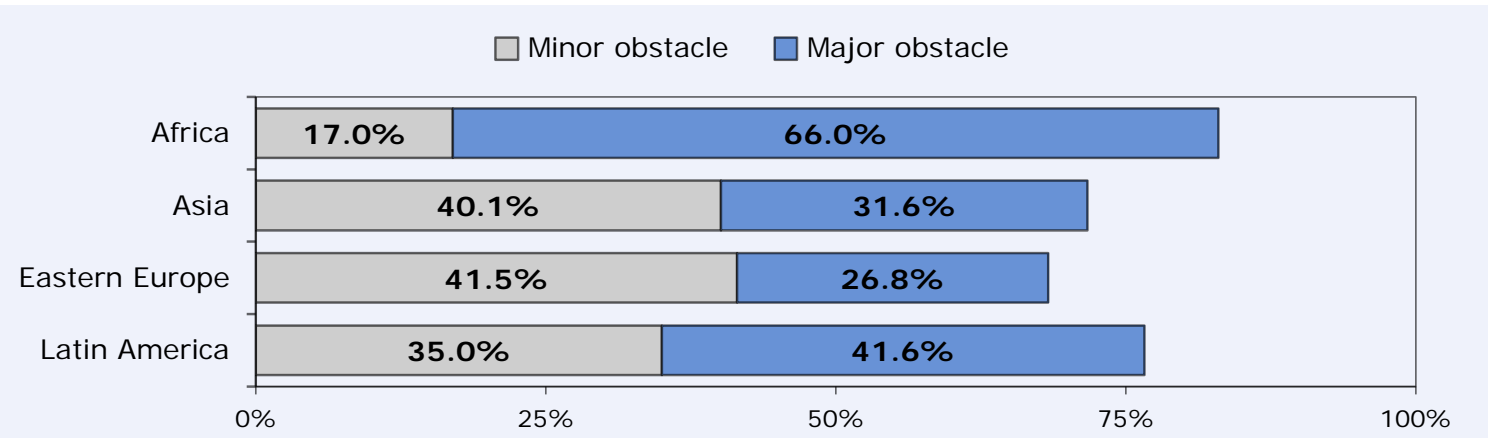

Source: CBI (2013), "Access to Trade Finance: First-hand Perspectives on Bottlenecks and Impacts for SME Exporters in the South", Ministry of Foreign Affairs of the Netherlands, Page 23. 
These results are corroborated by the 2014 Global Enabling Trade Report of the World Economic Forum (WEF). Published every two years, the Global Enabling Trade Report assesses the quality of institutions, general infrastructures and services available for trade. The WEF ranked the lack of access to trade finance as one of the most problematic factors for exporting in Africa, Latin America, the Caribbean and the Pacific Alliance (see Charts 3.4 and 3.5).

\section{Chart 3.4 The most problematic factors for exporting in Africa, WEF 2013}

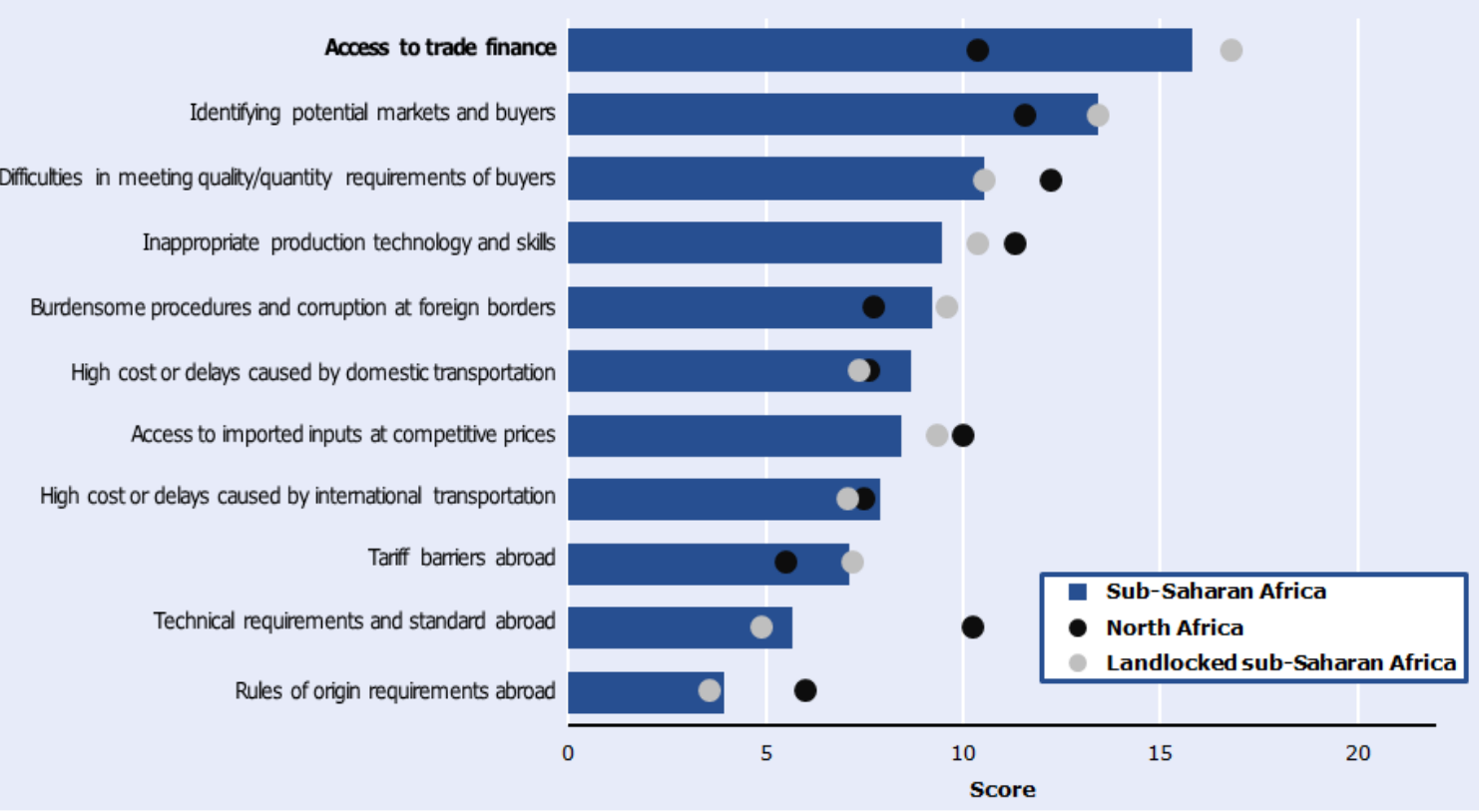

Note: $\quad$ From the list of factors above, respondents were asked to select the five most problematic ones for trading in their country and to rank them between 1 (most problematic) and 5 . The bars in the figure show the responses weighted according to their rankings.

Source: WEF (2013), "The Africa Competitiveness Report 2013", Executive Opinion Survey 2012.

Chart 3.5 The most problematic factors for exporting in Pacific Alliance and in Latin America and the Caribbean, WEF 2014

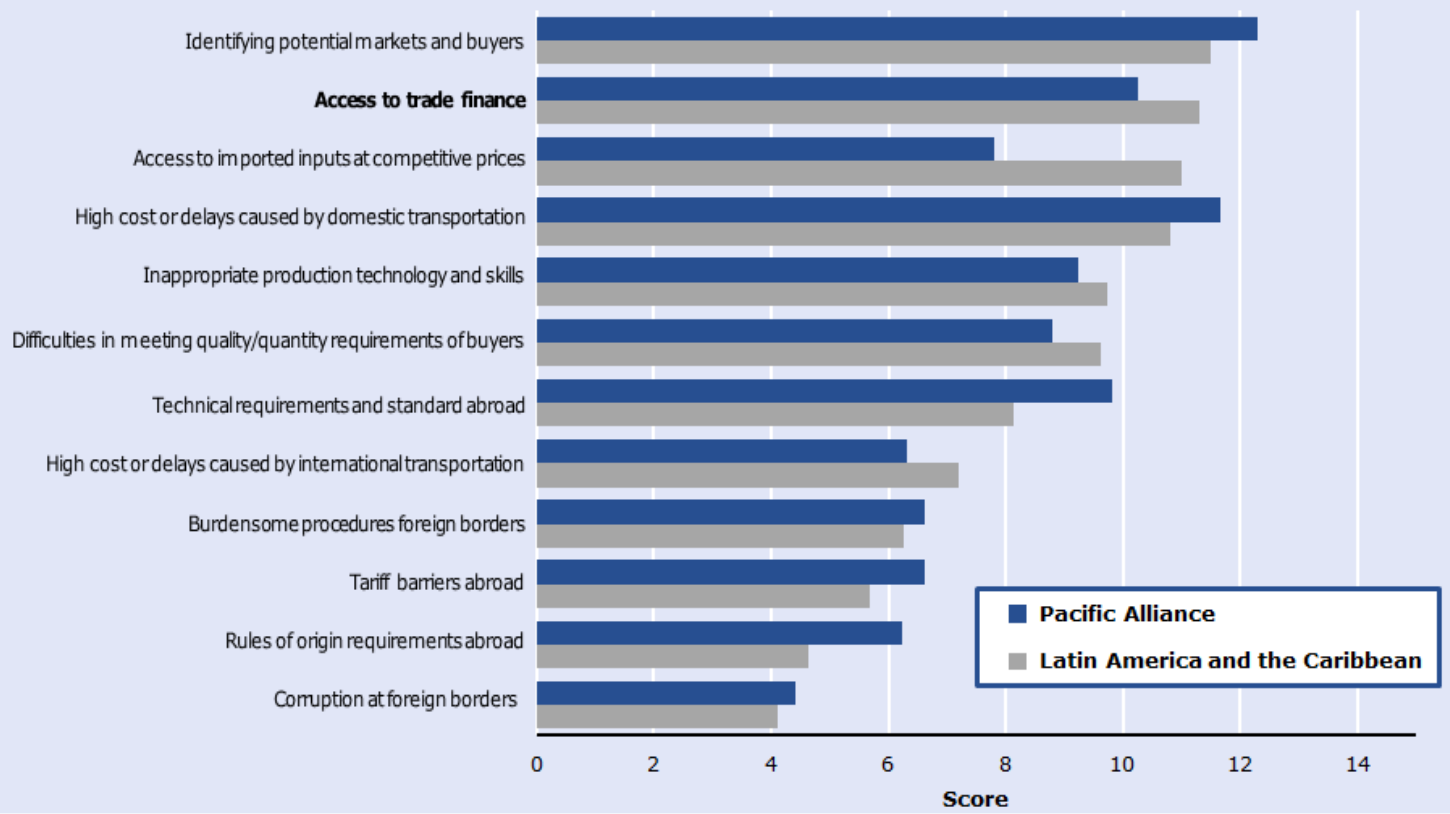

Note: $\quad$ Same methodology as Chart 3.4 is applied to this figure.

Source: WEF (2014), "Global Enabling Trade Report 2014", Executive Opinion Survey 2013. 
The latest International Chamber of Commerce (ICC) Global Survey 2014, based on data from 298 banks in 127 countries, confirms such findings. According to the survey, $41 \%$ of respondent banks acknowledged the existence of a shortfall in global trade finance supply, with an emphasis on SMEs and Africa. Amongst the main obstacles limiting the access of SMEs to trade finance are the increasing compliance and regulatory burdens as well as the low country and local banks' credit ratings (see Chart 3.6). In the survey, $70 \%$ of respondent banks recognized that there is a role to be played by Multilateral Development Banks in providing access to trade finance.

\section{Chart 3.6 I mpediments to Trade Finance according to respondent banks, I CC Global} Survey 2014

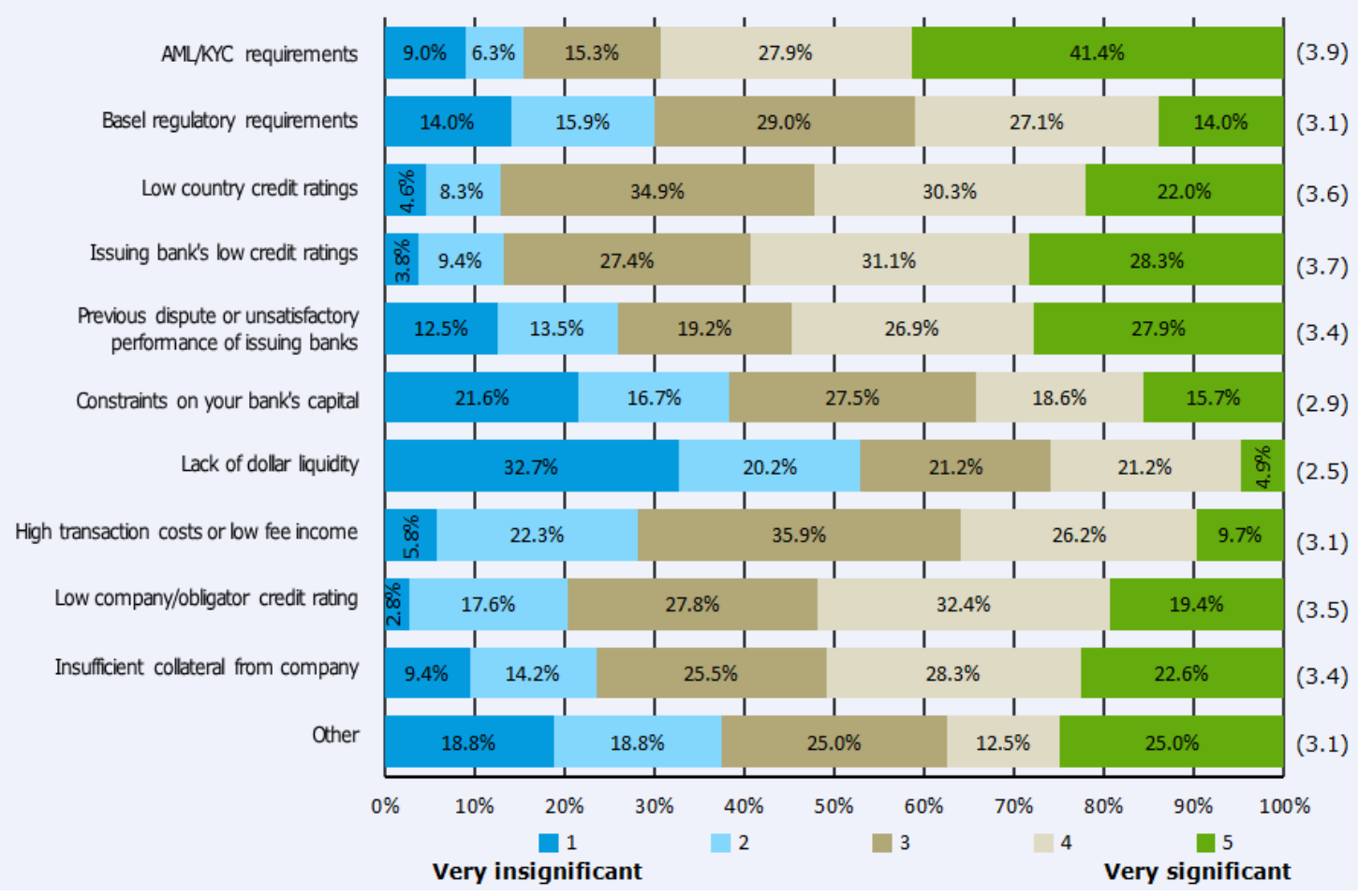

Note: $\quad$ Numbers in brackets are weighted averages of ratings. The closer the average rating is to 5, the higher the level of significance. An average rating close to 1 indicates a low level of importance.

Source: ICC (2014), "Rethinking Trade and Finance, ICC Global Survey on Trade and Finance", ICC Banking Commission.

Finally, with regard to the issue of financing trade in the context of international value chains, a survey conducted by the WTO with the OECD in 2013, as background for the $4^{\text {th }}$ review of Aid-ForTrade, concluded that lack of access to trade finance was a key element in the inability of low income countries to participate in global value chains (see Chart 3.7). 
Chart 3.7 Public views on the main barriers in connecting firms to value chains (percentage of responses)

Donors and providers of South-South assistance $\quad$ Partner countries

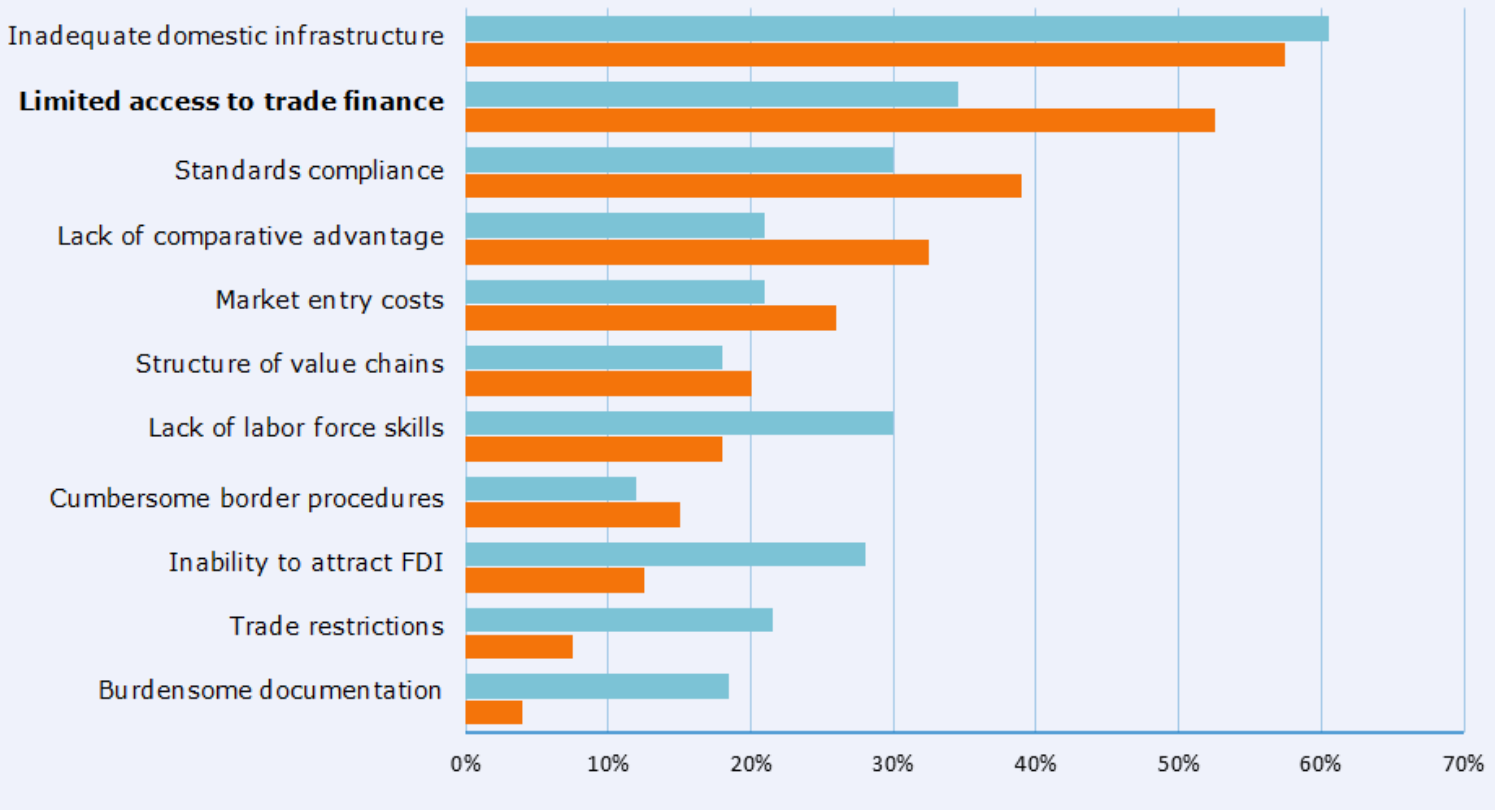

Source: $\quad$ OECD/WTO Aid-For-Trade Questionnaire Survey 2013 (for the $4^{\text {th }}$ Aid-for-Trade Review)

\section{ADDRESSI NG TRADE FI NANCE DI FFI CULTI ES I N DEVELOPI NG COUNTRI ES}

\subsection{Supporting MDBs in establishing a global network of trade finance facilitation programs}

In 2011, the Director-General of the WTO and President of the World Bank, with the support of the Heads of Multilateral Development Banks (MDBs) drew the attention of the international community to this problem which specifically affected low-income countries. The G-20 Seoul Summit Document indicated that:

"To support low income countries (LICS) capacity to trade (...), we note our commitment to (...) support measure to increase the availability of trade finance in developing countries, particularly LICs. In this respect, we also agree to monitor and to assess trade finance programs in support of developing countries, in particular their coverage and impact on LICs, and to evaluate the impact of regulatory regimes on trade finance." (Fighting Protectionism and Promoting Trade and Investment, Paragraph 44)

In the context of the G-20 mandate, the WTO Secretariat has reviewed the efforts already deployed by regional development banks and the World Bank Group (through the International Financial Corporation (IFC), its private sector arm) to support trade finance. These efforts are not insignificant, as summarized in Table 4.1. The Asian Development Bank (ADB), the European Bank for Reconstruction and Development (EBRD), the Inter-American Development Bank (IDB), the Islamic Development Bank (ITFC), and the IFC are operating relatively similar programs. In early 2013, the African Development Bank (AfDB) opened a permanent program and has already financed close to US $\$ 1$ billion in trade transactions in Africa and expects to support more than US $\$ 10$ billion over the next four years. The various institutions are often working in partnership. For example, the ADB has been working with the IDB and the AfDB to include member banks in each other's trade finance programs in order to encourage direct cross-continental relationships between banks and alleviate part of the South-South trade finance gap. 
The expansion of trade finance facilitation programs and similar schemes do not cost the taxpayer any money. These schemes are risk mitigation instruments that are run on a private-sector, demand-basis, with a focus on clients in developing countries, in particular the poorest. All institutions operating such programs are running net operating profits on it, while serving the wider purpose of facilitating trade in places of the word where private markets would not operate. These programs strengthen financial and trade inclusion in low-income countries. In effect, they provide risk mitigation capacity (guarantees) to both issuing and confirming banks, to allow for rapid endorsement of letters of credit - the main instrument used to finance trade transactions between developing countries players, and between developed and developing countries. The guarantee provided by the MDB ensures that the bank (typically the bank of the exporter) accepting to confirm a letter of credit (typically issued by the bank of the importer) will be paid even if the issuer fails to pay. The guarantee would ensure that the exporting bank is paid. Such guarantees are rarely called in but reduce the risk aversion of conducting trade operations in lowincome countries - as they close part of the "confidence gap" between the existing level of risk and its perception. The demand for these programs has increased during the 2009 financial crisis and has not fallen since.

All in all, trade finance facilitation programs from multilateral institutions have helped facilitate around US $\$ 30$ billion in trade in 2013, in the most challenging countries in the world. Almost a third of IFC's total operations took place in Sub-Saharan Africa and the ADB's risk-mitigation support mainly caters for the poorest regions in Asia, inter-alia, Pakistan, Bangladesh, Viet Nam, Sri Lanka, Nepal, and Uzbekistan.

Table 4.1 Overview of the main trade facilitation programs

\begin{tabular}{|c|c|c|c|c|}
\hline & EBRD & IFC & IDB & ADB \\
\hline Program title & $\begin{array}{l}\text { Trade Facilitation } \\
\text { Program (TFP) }\end{array}$ & $\begin{array}{l}\text { Global Trade Finance } \\
\text { program (GTFP) }\end{array}$ & $\begin{array}{l}\text { Trade Finance } \\
\text { Facilitation } \\
\text { Program (TFFP) }\end{array}$ & $\begin{array}{l}\text { Trade Finance } \\
\text { Program (TFP) }\end{array}$ \\
\hline $\begin{array}{l}\text { Number of countries in } \\
\text { operation }\end{array}$ & 23 & 96 & 21 & 18 \\
\hline $\begin{array}{l}\text { Program } \\
\text { commencement }\end{array}$ & 1999 & 2005 & 2005 & 2004 \\
\hline $\begin{array}{l}\text { Number of transactions } \\
\text { since commencement } \\
\text { (year end 31.12.2012) }\end{array}$ & 15,508 & 31,600 & 4,457 & 8,338 \\
\hline $\begin{array}{l}\text { Value of transactions } \\
\text { in } 2013\end{array}$ & EUR 1.2 billion & US\$22 billion & US\$1.21 billion & US\$4.03 billion \\
\hline $\begin{array}{l}\text { Number of confirming } \\
\text { banks }\end{array}$ & $800+$ & 1,100 & 297 & 124 \\
\hline Claims to date & 2 - no losses & zero & zero & zero \\
\hline
\end{tabular}

Note: $\quad \mathrm{ADB}=$ Asian Development Bank, $\mathrm{EBRD}=$ European Bank for Reconstruction and Development, $I D B=$ Inter-American Development Bank, IFC = International Finance Corporation.

Source: ICC. 2014. Rethinking Trade and Finance, ICC Global Survey on Trade and Finance. ICC Banking Commission. Geneva.

\subsection{New initiatives to meet the needs in low-income countries}

As shown by the WTO-OECD survey of 2013, lack of integration of low-income countries into international value chains is a major obstacle to their development (see Chart 4.1). In such countries, the ability of the local financial sector to provide supply chain finance arrangements is limited. Access to factoring locally is almost inexistent and SMEs are largely excluded from private supply-chain financing systems. To address this challenge, MDBs are extending receivable financing arrangements through local banks to help integrate small manufacturers from promising countries into international supply chains. The IFC has recently developed, as part of its trade finance program, 1) warehouse finance products which aim to extend working capital to small farmers and agriculture producers in food supply chains by leveraging their production, and 2) supply chain products aimed at providing short-term financing to exporters in emerging markets 
that sell to large international companies on open account terms. The ADB and the EBRD are also operating such supply chain products. These are welcome developments that have the potential to encourage a greater involvement of the private sector to extend "receivable financing" as well as to mobilise additional finance for trade activities and facilitate the integration of SME exporters/producers in supply chains.

As a collateralized commodity transaction, warehouse receipt finance is particularly relevant for the pre-export financing needs of the agriculture sector in emerging markets. Warehouse receipt financing is a lending technique that allows farmers/producers/traders of agricultural commodities to access bank loans by pledging their warehouse receipts issued against commodities deposited in licensed warehouses. There are a number of prerequisites for a well-functioning warehouse receipt market: an appropriate legal and regulatory environment, a support from local banks and commodity firms as well as a well-functioning commodity exchange that guarantees price transparency. Chart describes the functioning of IFC's Global Warehouse Finance Program and Global Trade Supplier Finance. To date, the Global Warehouse Finance Program has financed over US\$7.5 billion of commodity finance transactions in more than 41 countries, including Burkina Faso, Ethiopia, Ghana, Guinea Bissau, Kenya, Malawi, Senegal, Tanzania, and Uganda.

Chart 4.1 IFC's supply chain solutions
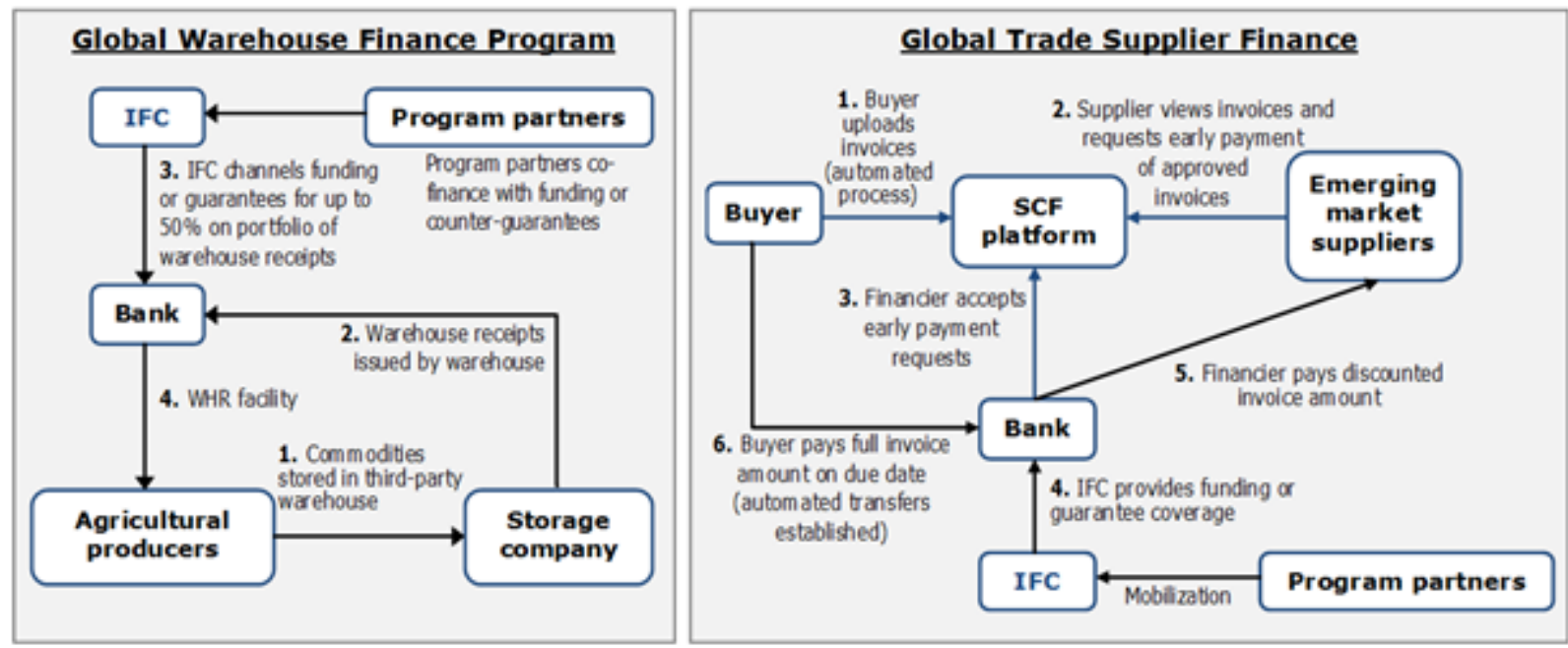

Source: IFC's Guide to Products: Global Trade \& Supply Chain Solutions, April 2012.

Private markets are also innovating to make trade finance more available to SMEs. In particular, factoring is the fastest growing source of short-term financing for SMEs suppliers. Unlike in a traditional lending relationship, factoring allows suppliers with weak credit ratings to access funding based on the value of their receivables (confirmed invoices). According to the ICC Global Survey (2014), Supply Chain Finance is one of the innovations most likely to change the trade finance industry, with $66 \%$ of bank respondents underlining the increasing importance of it for their bank. To further bring the benefits of supply chain finance to smaller suppliers, several developing countries are promoting the use of factoring facilities. In Mexico, the Cadenas Productivas program delivers cash against receivables via a secure and on-line technology platform. The Reserve Bank of India recently announced a "Trade Receivables Discounting System" or "TReDS", akin to the Mexican program.

\subsection{Avoiding the unintended consequences of Basel III on trade finance, particularly for developing countries}

Traditionally, trade finance - mainly letters of credit and other self-liquidating instruments of payments for trade - had received preferred treatment on the part of national and international regulators on grounds that trade finance was one of the safest, most collateralized, and selfliquidating forms of finance. This was reflected in the low credit conversion factor (CCF) determined under the Basel I framework for the capitalization of these instruments, which was set 
at $20 \%$, i.e., five times lower than any on-balance sheet loan. However, as the banking and regulatory communities moved towards internal rating-based and risk-weighted assets systems under the successor Basel II framework, issues regarding maturity structure and country risk emerged.

With the collapse of trade in late 2008 and early 2009, the regulatory treatment of trade credit under Basel II became an issue and was discussed by professional banking organizations, regulators and international financial institutions. A sentence made its headway into the communiqué of G-20 Leaders in London in April 2009, calling upon regulators to exercise some flexibility in the application of Basel II rules, in support of trade finance. Moreover, in the context of prudential re-regulation under Basel $\mathrm{III}$, requests were made to ask that trade finance, which had suffered casualties by contagion from other segments of the financial industry, should not be penalized. "Unintended consequences" of increased prudential regulation were to be avoided, particularly with respect to the ability of developing countries to access trade finance at an affordable cost. The banking community was asked by the then Director-General of the WTO, Pascal Lamy, to provide evidence about the high level of safety and soundness of their activity by collecting statistical information.

In parallel, the G-20 asked at the end of 2011 that the WTO and World Bank, on the one hand, and the Basel Committee on Banking Supervision (BCBS), on the other, engage in a dialogue with a view to improve common understanding of trade finance, and identify any possible "unintended consequences" of prudential regulation. This dialogue proved extremely useful, and, to some extent, has become commonplace. Prudential regulators have been able to improve their grasp on the workings of trade finance and to verify, thanks to the data collected by ICC under the "pilot" trade finance register, the low-risk character and absence of leverage of the industry. The aggregate data delivered by ICC covered more than 20 major international banks, over five million transactions, and revealed less than 1,150 defaults. Discussions with the Basel Committee have been conducted by the WTO and World Bank since 2011.

Since then, the BCBS has made three revisions reflecting the low level of risk of trade finance, and improving its regulatory treatment.

on 25 October 2011, the BCBS agreed to reduce the excessive risk-weighting requirements on low-income countries, and to waive the one-year maturity floor applying to letters of credit and the like. Both measures are of great importance in removing obstacles to the provision of trade finance in developing countries. ${ }^{14}$

on 6 January 2013, the new Basel III guidelines on liquidity (concerning the liquidity coverage ratio, LCR) proved to be favourable to short-term, self-liquidating trade finance instruments. ${ }^{15}$ In its Decision, the Committee allows national regulators to set very low outflow rates (between 0 and $5 \%$ ) for contingent funding obligations from trade finance instruments significantly below previous levels. Banks are allowed to hold fewer liquid assets against contingent trade liabilities, thereby increasing the availability of trade finance.

on 12 January 2014, the BCBS reduced the leverage ratio on trade letters of credit and other self-liquidating trade-related instruments, to reduce it from a $100 \%$ CCF to a $20 \%$ CCF (such for capital purposes) and $50 \%$ for trade guarantees. ${ }^{16}$ The 2014 modification was hailed by the Director-General of the WTO "as being of particular significance for the availability of trade finance in the developing world, where letters of credit are a key instrument of payment. This is good news for developing countries, for the expansion of their trade and for the continued growth of South-South trade flows."17

\footnotetext{
${ }^{14}$ This decision is explained in the document "Treatment of trade finance under the Basel capital framework" of the BCBS, available at http://www.bis.org/publ/bcbs205.pdf.

${ }^{15}$ Details via press release: http://www. bis.org/press/p130106.htm, 6th J anuary 2013.

${ }^{16}$ The revised Text - "Amendments to Basel III's leverage ratio issued by the Basel Committee" - is available on http://www. bis.org/press/p140112a.htm, 12 ${ }^{\text {th }}$ January 2014.

${ }^{17}$ WTO news, "Azevêdo hails Basel decision on trade finance as good news for developing countries", available on http://www.wto.org/english/news_e/news14_e/dgra_17jan14_e.htm, 17 $7^{\text {th }}$ January 2014.
} 
The situation on the regulatory front is looking better than it did a few years ago, thanks to the institutional dialogues opened by the WTO and the Basel Committee, and the data support provided by ICC. There is no doubt that such initiatives have contributed to improving the policy coherence between the prudential and central bank community on the one hand, and the trading community on the other.

\subsection{Enhancing the capacity of the local banking sector to support trade}

While global lenders tend to refocus on their main customers, opportunities are left for local and regional banks to step in when they have the capacity to do so. Tier 1 and 2 banks in the AsiaPacific region (China, Republic of Korea, Chinese Taipei, Indonesia, Malaysia), in Latin America (Brazil, Columbia) and in the Middle East and Eastern Europe are increasing their market shares in the trade finance space. In Africa, according to Yaw Kuffour, lead trade finance specialist at the African Development Bank, "Some of the big players from Nigeria, Kenya and South Africa are trying to do more [...] to mobilise resources and channel them to this market." ${ }^{18}$ However, "African banks still lack the critical mass and muscle to provide the necessary credit so there is a need for Development Finance Institutions' intervention." According to the AfDB's "Trade finance in Africa" survey (2014), the vast majority of African commercial banks invest in trade transactions, contributing on average for $17 \%$ of their earnings. While a large number of confirming banks are based outside Africa, the study acknowledged the growing role of African-based confirming banks, though banks in Northern Africa dwarfs those of the other sub-regions. Yet, African lenders are still constrained by the relatively small size of African banks' balance sheets. For instance, the African Export-Import Bank (Afreximbank), received demand for products in excess of US $\$ 23.8$ billion in 2013 , but could only process $\$ 2.68$ billion worth of transactions.

Hence, efforts aimed at strengthening the capacity of developing countries to finance their own trade and in building the know-how to handle trade finance instruments are needed. From that perspective, trade finance facilitation programs can bring additionality in low-end markets and increase capacity for smaller local commercial banks as well as to connect them with global confirming banks. Box 4.1 illustrates how the Asian Development Bank supports these objectives in Myanmar.

To this aim, donor technical assistance funds are being used by all institutions offering these programs to train bankers in developing countries through seminars or in-situ training (in particular through the IFC and EBRD dedicated trust funds for trade finance training). ECAs have also been very active in institutional building, with Berne Union ECAs (NEXI from Japan, US EXIM, Euler-Hermes from Germany, COFACE, ECAs from Nordic Countries) providing technical assistance to set up counterpart ECAs in least developed countries. For example, some ECAs have been active in supporting the creation of regional ECAs in Africa, and provided in-situ training.

\section{Box 4.1 Operating in new frontier countries: the ADB's trade finance program in Myanmar}

Alongside an expanding trade finance scheme for banks and a supply chain finance facility, the ADB's Trade Finance Program (TFP) aims to strengthen the financial sector governance in some of the participating countries. Covering already 18 countries, ADB's TFP is about to expand the initiative to Myanmar.

After decades of isolation, finance is a binding constraint on Myanmar's future development. Its banking system and commercial regulatory infrastructure are at an early stage of development and trade transactions are conducted to a large extent on a cash basis. For banks in countries with little experience in trade finance, such as Myanmar, ADB's due diligence credit risk assessment process and training seminars on trade finance are making an important contribution to building the institutional capacity and expertise of local issuing banks to conduct trade finance operations. In 2013, ADB's TFP performed substantial due diligence reports and five private sector banks have been accepted as issuing banks for the program, with a total country exposure limit of US\$10 million.

The IFC has also accepted to open a US $\$ 5$ million trade line and to provide advisory services to one local bank in Myanmar as well.

${ }^{18}$ Retrieved from the magazine "This is Africa", available at http://www.thisisafricaonline.com/News/African-banks-look-to-fill-trade-finance-gap, $26^{\text {th }}$ J une 2013. 


\subsection{Looking into the future: What more can the WTO do?}

\subsubsection{Continue the diagnosis and advisory role}

By continuing to monitor closely the market situation, the WTO should be in a position to alert the international community and to mobilize all actors, whenever needed. Recently, the WTO and its partners have been considering the policy lessons of the recent crisis, for example in World Bank (2011) and in WTO (2013). This "return on experience" may help improve any contingency plan in the future. The WTO will continue to inform on a regular basis its members and the G-20 about the persistent financing gaps, particularly at the low end of the market as well as to ensure that the solutions proposed by the public sector meet the demand from trade bankers and traders where additionality is most needed. In this respect, the group of Experts and Members' own information should continue to be shared within the context of the Working Group on Trade, Debt and Finance, as part of this ongoing monitoring.

\subsubsection{Support the availability of trade finance in developing countries}

The WTO contributes to support and contribute to evaluate the efforts by Multilateral Development Banks (MDBs) in addressing the structural trade finance gap in developing countries. WTO support helps trade finance issues to be raised, whenever needed, in such fora as the G-20. Since the creation of the G-20, trade finance issues have been dealt with under the trade Track, thereby gaining enough visibility for leaders.

\subsubsection{Encourage synergies in the field of technical assistance}

The WTO works with MDBs, export credit agencies and the private sector to disseminate knowledge and information on trade finance. The WTO Secretariat has developed e-Learning modules available from the WTO website. Technical assistance on the ground (in banks and at the level of traders) is already provided by MDBs, through trust funds (e.g. ICC and EBRD), and the ICC. The ICC is currently in the process of creating a "trade finance Institute", which will draw on existing MDBs and WTO e-learning materials. The pooling of such resources is a welcome development for the traders and the bankers. 


\section{BI BLI OGRAPHY}

ACE International Consultant (2013), "Feasibility Study of an ACP Investment Bank Project", March 2013, 2012/290369/1, Retrieved from http://www.acp.int.

African Development Bank (2014), "Trade Finance in Africa", Economic and Financial Governance, Trade Finance Program, December 2014, Abidjan: African Development Bank.

Amiti, M. and Weinstein, D. E. (2011). "Exports and Financial Shocks", The Quarterly Journal of Economics, 126 (4), 1841-1877.

Asian Development Bank (2014), "ADB Trade Finance Gap, Growth, and Jobs Survey", ADB Briefs No. 25, December 2014, Manila: Asian Development Bank.

Auboin, M., and Engemann, M. (2013), "Testing the Trade Credit and Trade Link: Evidence from Data on Export Credit Insurance", Staff Working Paper ERSD-2012-18, Geneva: WTO.

Baldwin, R. (2009), "The Great Trade Collapse: Causes, Consequences and Prospects", Retrieved from VoxEU.org Ebook, 27 November.

Bank of International Settlements (2014), "Trade Finance: Developments and Issues", CGFS Papers, No 50.

Bricongne, J.-C., Fontagné, L., Gaulier, G., Taglioni, D. and Vicard, V. (2012), "Firms and the global crisis: French exports in the turmoil", Journal of International Economics, Elsevier, vol. 87(1), pages 134-146.

Centre for the Promotion of Imports from developing countries (CBI) (2013), "Access to Trade Finance: First-hand Perspectives on Bottlenecks and Impacts for SME", Ministry of Foreign Affairs of the Netherlands.

Chor, D. and Manova, K. (2009), "Off the Cliff and Back? Credit Conditions and International Trade During the Global Financial Crisis", Retrieved from SSRN, December 15.

Chor, D. and Manova, K. (2012), "Off the Cliff and Back? Credit Conditions and International Trade during the Global Financial Crisis", J ournal of I nternational Economics, 87, 117-133.

Eaton, J., Kortum, S., Neiman, B. and Romalis, J. (2011), "Trade and the Global Recession", National Bureau of Economic Research Working Paper Series, No. 16666.

Eichengreen, B. and O'Rourke, K. H. (2012), "A tale of two depressions redux", Retrieved from VoxEU.org, 6 March.

IMF-BAFT (International Monetary Fund-Bankers' Association for Finance and Trade) (2009), "I MFBAFT Trade Finance Survey: A Survey Among Banks Assessing the Current Trade Finance Environment.", report by FImetrix for IMF and BAFT, Washington, DC

International Chamber of Commerce (2009), "Rethinking Trade Finance 2009: An ICC Global Survey", ICC Banking Commission Market Intelligence Report.

International Chamber of Commerce (2013), "Global Risks - Trade Finance Report 2013", ICC Banking Commission.

International Chamber of Commerce (2014), "Global Survey 2014: Rethinking Trade and Finance", ICC Banking Commission, available at http://www.iccwbo.org/about-icc/policycommissions/banking/.

International Monetary Fund (2003), "Trade Finance in Financial Crises: An Assessment of Key Issues", Policy Development and Review Department. Washington DC: IMF Board Paper.

World Bank (2011), "Trade Finance during the Great Trade Collapse", World Bank Publications, Edited by Chauffour, J.-P. and Malouche M., Washington DC: The World Bank.

World Economic Forum (2014), "Global Enabling Trade Report 2014", Geneva, Switzerland. Retrieved from http://www.weforum.org/reports/global-enabling-trade-report-2014.

World Trade Organization (1998), "Trade Policy Review - Indonesia", Geneva.

World Trade Organization (2004), "Improving the Availability of Trade Finance During Financial Crises", WTO Discussion Paper 2, by Auboin, M. and M. Meier-Ewert. Geneva: WTO.

World Trade Organization (2013), "Trade finance in periods of crisis: what have we learned in recent years?", by Auboin, M., and Engemann, M., ERSD Working Paper, Geneva: WTO. 